\title{
Автоматизм соціальної практики як родова атрибуція поняття
}

\author{
Настояща К. В., Київський національний університет імені Тараса Шевченка
}

Стаття присвячена аналізу поняття практики, основній його атрибуції. Неусвідомлюваність, автоматизм визначається як родова атрибуція цього поняття. Ця характеристика є загальною для практик незалежно від того, з якої позиції вони розглядаються і до якого типу належать. Саме вони визначають практику, як практику, відрізняючи iі від інших елементів культурної системи. Саме неусвідомлюваність як характеристика практики стала причиною того, що практики часто називаються фоновими, латентними. Багаторазова повторюваність практики протягом життя робить іiі автоматичною і виміщає пов'язану з нею природню установку в підсвідоме людини, а культурно - в той самий фон повсякденності, через який практика настільки сприймається як належне і звичайне, що не помічається, стає невидимою. Практика виконує механічні прості задачі існування нашого тіла в соціумі, i разом із цим вона $є$ тим, що нас культурно вбудовує в цей соціум, робить нас його елементом. Так, саме практика стає тим локусом перетину каузального з духовним, як культурним, видимого з невидимим, стає емпірично доступним мереживом кордонних значень, харизматичних змістів культури, які піддаються візуалізації.

Ключові слова: практики; атрибуції практики; неусвідомлюваність; автоматизм; практична свідомість; природня установка

\section{Automatizm of social practice as a generic attribution of the concept}

\section{Nastoiashcha K. V., Kyiv National Taras Shevchenko University}

The article is devoted to the analysis of the concept of practice, its main attribution. Unconsciousness, automatism defined as the generic attribution of this concept. Unconsciousness, as a characteristic of practice, has become the reason why practices are often called backgrounds, as unobserved. That is, such as the background, in the shadow, latent. An explanation of why this happened is found in works of A.Giddens. So most actions, according to A.Giddens, are not directly motivated (that is, motivations are usually not understood). Another words, the motivation (conscious) does not necessarily have to be present in each action. In this sense, A.Giddens identifies two types of consciousness: discursive and practical, when the latter plays a fundamental role in structuring.

Practical consciousness thus consists of a common understanding that is distributed among individuals, which is fundamental to social life, but is not clearly understood (verbalized and reflexive). After all, practical knowledge, practical consciousness is the basis of the natural set. And if the set in general in this context can be understood in a classical way, following D. Uznadze, that is, as something that is hidden, but determining a casual one, then the natural set can be understood in the original Schutz's phenomenological interpretation.

In this sense, the natural set corresponds to the institutional level of practice. That is, it remains part of the consciousness (even in psychoanalytic distributions), but it is not reflected and articulated by the individual. From unconsciousness also flows automation of practice. Since hypothetically not every unconsciousness necessarily involves automatism, it should be noted that this is an important feature that gives us an understanding that practice is always automatic. So automaticity is formed from repetitiveness, because every practice every person repeats in his life many times.

Maybe somehow transform the implementation due to the state of health, as a tribute to the fashion, etc., but this will not change the function of practice (read its contents), and the practice remains repetitive. It is the repetition of practice throughout life, often from the childhood, makes it automatic and moves into the pre-conscious, the subconscious (according to V. Nalimov), in the same background of everyday life, through which the practice is so perceived as proper, the usual, which is not realized, becomes automatic.

Keywords: practice; attribution of practice; unconsciousness; automatism; practical consciousness; natural set

\section{Автоматизм социальной практики как родовая атрибуция понятия}

\section{Настоящая К. В., Киевский национальный университет имени Тараса Шевченко}

Статья посвящена анализу понятия практики, основной его атрибуции. Неосознаваемость, автоматизм определяется как родовая атрибуция этого понятия. Эта характеристика является общей для практик независимо от того, с какой позиции они рассматриваются и к какому типу относятся. Именно они определяют практику как практику, отделяя ее от других элементов культурной системы. Именно неосознаваемость как характеристика практики стала причиной того, что практики часто называются фоновыми, латентными. Многократная повторяемость практики в течение жизни делает ее автоматической и вымещает связанную с ней естественную установку в подсознательное человека, а культурно - в тот самый фон повседневности, из-за которого практика настолько воспринимается как должное и обычное, что не замечается, становится невидимой. Практика выполняет механические простые задачи существования нашего тела в социуме, и вместе с этим она есть тем, что нас культурно встраивает в этот социум, делает нас его элементом. Так, практика становится тем локусом пересечения каузального с духовным, как культурным, видимого с невидимым, становится эмпирически доступным кружевом пограничных значений, харизматичных смыслов культуры, которые способны к визуализации.

Ключевые слова: практики; атрибуции практики; неосознанность; автоматизм; практичное сознание; естественная установка 


\section{Постановка проблеми.}

«Там, де було суспільство - постала культура», - писав Г. Белл, тому не дивно, що сьогодні з'являється все більше галузей соціології, які вивчають сферу культури, налаштовуючи оптики своїх методологій на пізнання найменших деталей. I візуальна соціологія, і соціологія тілесності, і соціологія технологій, і теорія фреймів, як і «Соціологія повсякденності», яка сьогодні «удочерила» поняття практики, вийшли своїми коренями з соціальної теорії культури. Аналізуючи іiі стан і трансформацію сьогодні, А. Реквіц, зокрема, виділяє чотири iii напрямки, чотири версії культуральної теорії, за кожною $з$ яких стоїть авторитетна філософська, антропологічна, семіотична, феноменологічна та соціологічна традиція, а саме: менталізм (дослідник зосереджується на когнітивних структурах та актах інтерпретації), текстуалізм (соціальне репрезентоване системою знаків і символів, дискурсами та комунікаціями і становить певний текст), інтерсуб'єктивізм (соціальне як взаємодії індивідів), і власне сама теорія практик [1].

В останній, тій яка нас буде цікавити, соціальний порядок інтерпретується як порядок практик, а самі практики - це рутинізований тип поведінки, який складається 3 кількох елементів, що пов'язані один $з$ одним: форм тілесної активності, форм ментальної активності, «речей» та їхнього використання, фонове знання у формі розуміння, know-how, стану емоцій та мотиваційного знання.

На відміну від соціологічних теорій, націлених на виявлення істини і подання узагальненого знання про об'єкт або дослідження, теорії соціальних практик сфокусовані на виявлення характерних тенденцій сучасного суспільного розвитку. Вони відкриті не тільки для раціональних, але й для ірраціональних понять. «Практики конституюють i відтворюють ідентичності або «розкривають» основні способи соціального існування, можливі в даній культурі і в даний момент історії», - пише П. Штомпка [2]. Разом із тим, теорія практик - це соціологія «тут і зараз». «Жодні трансцендентні сенси, цінності, всеосяжні левістроссівські структури не дозволяють нам вирватися з ситуації «тут i зараз» і зробити якісь генералізовані зіставлення», - пише В. Вахштайн [3]. На сьогодні теорія практик, незважаючи на свою різновекторність, є більш-менш відносно цілісною теорією, яка, пройшовши довгий шлях, сформувала низку оптик, де практику можна розглядати 3 різних позицій, i залежно від цих позицій ми можемо виділити різні характеристики цього явища. Розтлумачимо наше твердження грунтовніше, проаналізуємо основні оптики.

Так, практику, як у класичній теорії практики, так і в теорії культури, визначають і як елемент структури (культури, соціуму), і як точку перети- ну змісту і каузальності, смислу і структури, і як зустріч макро- і мікрорівнів аналізу, об'єктивістського і суб'єктивістського підходів. Концепт структурацій Е. Гідденса, який хоча і звинувачують в еклектичності залишається вдалою спробою артикулювати практики, як вирішення дилеми між агентом і структурою, що первинно і досить результативно робить ще П. Бурдьо, вводячи поняття габітуса [4]. Обидва підходи дуже відмінні, проте їх об'єднує не тільки постструктуралістька методологія, але і акцент на тілесності практик, їх рутинності; хоча обидва концепти не позбавлені недоліків і залишають відкритими ряд питань, вони вагомо поповнили теорію практик, розкривши їі евристичний потенціал на новому рівні, рівні вже макропроцесів. Так, саме роботи Е. Гідденса i П. Бурдьо створили грунт для подальшого переосмислення практик у фокусі вже латурівської перезборки соціального, аналізу основної атрибуції практики - неусвідомлюваності.

Аналіз як класичних робіт, так і останніх досліджень свідчить, що процес вичленення практики з фону, контексту, розрізнення від інших дій, які практикою не є, передбачає вибір тих критеріїв, які роблять практику практикою. На основі аналізу праць апологетів теорії практики, як класиків (у цей список занесемо Е. Дюркгейма, М. Хайдеггера, М. Фуко, М. Мосса, Н. Еліаса, П. Бурдьо, Б. Латура, Ж. Дельоза, К. Гірца, Г. Гарфінкеля, А. Реквіца, А. Шюца, І. Гофмана), так і сучасників (В. Волкова і О. Хакордіна, Д. Гінева, П. Штомпку, В. Вахштайна та ін.) ми можемо виділити наступні критерії практики, які визначають iii як таку і відрізняють іiі від різноманітності дій та рухів: перше - неусвідомлюваність, друге - автоматизм виконання, третє - повторюваність, четверте - культурообумовленість, п'яте - тілесність, шосте - рухливість, сьоме - індексичність, вимірюваність, восьме - правилообумовленність, конвенційність.

Метою нашої статті буде аналіз саме першого критерію, першої визначальної атрибуції - автоматизм практики.

Виклад основного матеріалу.

Так, практики (релігійні, політичні, економічні, приготування їжі тощо) являють собою складні утворення, в яких розрізняють комплекс розумінь, адекватних діям, колекцію правил та «телеоафективну структуру», тобто нормативну, ієрархічно впорядковану систему цілей, проектів, завдань, емоційних станів [5, р. 191-192]. Апологети теорії практик загалом стверджують, що «світ взаємодій між людьми - це світ різноманітних практик (суто фізичних дій i суто ментальних конструкцій), сплетених у щільну мережу» [4].

Укоріненим у таке визначення практики $є$ i те, що, розглядаючи іiі як певний «спосіб діяти i 
говорити», вона є зрозумілою не тільки для того, хто виконує таку практику (тобто, носія практики), а й для всіх потенційних спостерігачів або реципієнтів, принаймні у межах однієї культури. Таким чином, практики є рутинізованим способом пересування тіл, маніпулювання предметами, ставлення та поведінки щодо інших, опису речей i розуміння світу. В цьому сенсі визначення практик як соціальних (або соціокультурних) є тавтологічним - вони є соціальними, бо є «типом» поведінки та розуміння, які проявляються у різних локальностях та моментах часу, виконуються різними тілами / ментальностями (minds) [6, с. 249-250].

Те, що практики самі по собі також складають, утворюють будь-яку культуру, бо детерміновані суспільними міфами, ідеологіями в своїй змістовній частині і складають вже власною інструментальною (каузальною) складовою елементарні одиниці структури останньої - обряди, ритуали, норми, правила, є темою окремого дослідження. Звертаючись же до цих понять і максимально абстрагуючись при цьому, ми побачимо що всі ці структурні елементи культури, як то обряди, ритуали, норми і правила, є нічим іншим, як тими самими практиками як функціонально, так і змістовно, але просто за формою вони є складнішими, масивнішими, усвідомлюваними, бо вони всі, на відміну від практик, які їх утворюють, є досить яскравими унікальними феноменами, що органічно усвідомлюються як унікальні і вплітаються в тканину культури дивовижними візерунками.

Як орнамент персидського килима є одночасно унікальним культурним кодом, так і обряди, ритуали, правила, норми є такими, що усвідомлюються в цілому як єдина велика практика, а разом iз цим тривають послідовною зміною неусвідомлюваних, автоматичних практик, бо складаються 3 мікропрактик, які одночасно їх утворюють. Візьмемо для прикладу весільний обряд, ритуал поховання або правила дорожнього руху. Все це - унікальні культурні елементи, які складаються 3 дрібних повсякденних практик, тобто дій автоматичних, які не усвідомлюються і є тлом, заднім планом спільного масштабного унікального культурного інсценування.

Але чи може усвідомлене бути утвореним тим, що не усвідомлюється? Як можливо, щоб ми розототожнилися і побачили себе поза межами навіть цього неусвідомленого, яке є фоновим настільки, що ми не тільки його не аналізуємо, але навіть не помічаємо? Це питання дуже хвилювало М. Хайдеггера. Саме $з$ цих пошуків народилося його розуміння того, що він називав «проблисками буття» [7]. Практики для нього в цьому сенсі були саме проблисками, тому що розуміння і усвідомлювання практик завжди стикалося 3 тим, що відтворення практик $є$ автоматичним, тілесним. Тіло звикло, призвичаїлося до певних рухів, операцій, маніпуляцій, алгоритму дій, послідовності, правил виконання, які були тлом, фоном конкретних дій.

Подібне розуміння фону знову повертає нас до потреби розототожнення 3 автентичним культурним контекстом при аналізі практик, і першим етапом цього розототожнення може бути, як це не дивно, сам факт усвідомлення. Усвідомлення безпосередньої очевидності тієї чи іншої практики, даної як об'єкт певного фону, змушує нас міняти оптику бачення самої практики як чогось такого, що, незважаючи на свою звичайність, є в рамках дослідження певною мірою сакральним кодом ключем для пізнання через звичність практики природи унікального в культурі.

Саме неусвідомлюваність як характеристика практики стала причиною того, що практики часто називаються фоновими, тобто такими, що не помічаються, такими, які є тлом, знаходяться в тіні, є прихованими, латентними. Але якщо латентність передбачає рано чи пізно об'єктивацію, то латентність практик є тотальною. Пояснення того, чому так сталося, знаходимо у Е. Гідденса. Так, більшість дій та вчинків, за Е. Гідденсом, не є прямо мотивованими (тобто мотивації, як правило, не усвідомлюються). 3 іншого боку, найбільш раціонально ефективні дії стають рутинізованими, а отже необхідність їх «постійного мотивування» начебто зникає. Все це веде до того, що у соціальній дії рефлексивність і раціоналізація присутні постійно, тоді як мотивація $є$ потенційно можливою. Тобто мотивація (свідома) не обов'язково повинна бути присутня у кожній дії.

У цьому сенсі Е. Гідденс виділяє два види свідомості: дискурсивну і практичну, коли остання грає принципову роль у структурації. Причому практичну свідомість можна розташувати між дискурсивною свідомістю, яку індивід «усвідомлює» та рефлектує, та підсвідомістю (у визначенні 3. Фройда), яку можна осягнути тільки за допомогою психоаналізу. Таке розуміння практичної свідомості поєднує його і є частково запозиченим 3 феноменології А. Шюца та пізньої філософії мови Л. Вітгенштайна) [6, с. 249-250].

Так, Е. Гідденс говорить: «[Більш] важливими є сірі області практичної свідомості, які існують у відносинах (relation) між раціоналізацією дії і сукупністю знань актора; і між раціоналізацією діï і підсвідомістю. Сукупність знань (stocks of knowledge), у термінах А. Шюца, або те, що я називаю загальне (mutual) знання, використовується i реалізується акторами у продукуванні соціальних подій, але зазвичай не є доступною їм у чітко кодифікованій формі...» [6, с. 58].

Практична свідомість, таким чином, складається зі спільного розуміння, що розподіляється між індивідами, яке принципове для соціального 
життя, але не є чітко усвідомлюваним (вербалізованим і рефлексованим). Тобто залишається саме частиною свідомості (навіть за психоаналітичними розподілами), проте не рефлектується та артикулюється індивідом.

Така диспозиція усвідомленості практик, слідуючи за Е. Гідденсом, припускає потенційну можливість певної артикуляції чи рефлексії практичної свідомості або знання у разі виникнення потреби чи відповідних умов. Ідея «безпосереднього знання» (тут - tacit knowledge), хоча й видається аналітично і логічно самозаперечливою i парадоксальною (знання, знання про яке відсутнє), але все ж таки концептуалізується як таке, що ми знаємо дуже добре, але застосовуємо настільки часто і несвідомо в наших інтеракціях, що воно «зникає» 3 поля зору. Це щось, що розуміється як невизнане розуміння, те що «отримується як таке», як даність, у термінах А. Шюца - «is taken for granted». Отже, можна говорити про розрізнення дискурсивної свідомості - як «самосвідомості», коли ми повністю певні того, що ми знаємо; та практичної свідомості - як «свідомості», коли ми знаємо, але приймаємо це знання без визнання цього) [6].

Свідомість у цьому сенсі можна розглядати не за типами-рівнями, як у Е. Гідденса, а за рівнями відтворення-функціонування, як у В. Налімова, який у своїй книзі «Спонтанність свідомості» виділяє чотири рівні свідомості, при цьому рівень, означений ученим як рівень передсвідомості, відповідає саме за формування неусвідомлюваних, рутинізованих дій, які ми визначаємо як практики. Цей рівень, межуючи з рівнями підсвідомості (простір колективної підсвідомості й архетипів масової свідомості) і рівнем формальної логіки (на якому, власне, і відбувається усвідомлення і раціоналізація), функціонально відповідає за транзит смислів $з$ першого рівня на третій і навпаки [8].

Концепція В. Налімова схожа на концепцію А. Клюєва і А. Качалкіна, які внутрішню діяльність суб'єкта розділяють на п’ять рівнів - інтуїтивний підсвідомий, розумовий, емоційний, рефлекторний і інтуїтивний надсвідомий. «Внутрішній процес переробки людською свідомістю може бути або синхронізований у часі зі спостережуваним (контрольованим) зовнішнім процесом, або свідомість спостерігача функціонує в десинхронізованому режимі - відстаючи в часі від спостережуваного (контрольованого) процесу, або ж випереджаючи його» [9]. У випадку з практикою десинхронізація є постійною, хронічною. Адже відбування процесу сприйняття практики опосередковане рядом процесів, зокрема - передмисленням як першою фазою усвідомлення, що триває шляхом інсталяції різноманітних емоційно забарвлених образів-асоціацій. Так триває процес формування установки протягом соціалізації-культурації шляхом постійного повторювання комплексу одноманітних дії. Під час такого багаторазового повторювання часто відбувається десакралізація культурного смислу дії і дія стає рутинною, звичайною, автоматизованою, перетворюється в практику. Так, у процесі соціалізації триває «осад» «харизматичних змістів» колективної свідомості в індивідуальну. Людина відтворює ту чи іншу дію часто не відрефлексовуючи значення і контекст, що вже обумовлено енергозбережувальною функцією практики.

Цей процес потребує, однак, поглибленої концептуалізації і $є$ предметним полем скоріше психології і соціології пізнання. Зараз же відзначимо те, що видається важливим - знаходження практик, тобто центром їх керування $\epsilon$ рівень практичної свідомості, або, в термінології В. Налімова, рівень передсвідомості, кордонний рівень взаємодії свідомого і підсвідомого, на якому починається передмислення і домінують установки - образи, детерміновані колективним підсвідомим.

I тут не можна обійтися без розуміння того, що глибино кожна практика має корені в певній установці. Адже практичне знання, за Е. Гідденсом, є грунтом, джерелом природної установки. I якщо установку як таку в цьому контексті можна розуміти класично, слідуючи за Д. Узнадзе, тобто як те, що є схованим, але визначаючим казуальне [10], то природня установка може розумітися в первинно шюцевській, феноменологічній інтерпретації, в якій і визначає іiі і Е. Гідденс [11]. У цьому сенсі природня установка відповідна інституційному рівню відбуття практик і відмінна від установки екзестенційної, яка, на думку екзистенціалістів, відображає найменш об'єктивовану, спонтанну, деавтоматизовану і рефлексивну площину свідомості [12]. Ту площину, яку можна визначити як рівень підсвідомості, інтуїції, рівень колективного підсвідомого, архетипів. Обидва види установок, безумовно, пов'язані і хоча цей зв'язок не очевидний, він є об'єктом уваги екзестенційної соціології, соціології пізнання, теорії фреймів і т. д.

Повертаючись же до практики, підкреслимо, що вона має зв'язок 3 установкою нав'язаною і закріпленою в процесі соціалізації-культурації. Можна сказати, що кожній практиці передує установка, і коли практика сформована і закріплена, установка деактивується, переміщається в несвідоме. Саме процес соціалізації-культурації як темпорально-топологічний життєвий простір конкретної особи, робить установку природною, тобто переводить і1і на рівень не усвідомлення, чим зводить практику до форми інституціального автоматизму. У всіх сферах життя формуються такі установки, які детермінують побутові, звичаєві 
рутинні практики, полегшуючи життя. Навіть утилітарна практика тут і зараз так чи інакше детермінується певною установкою, яку реципієнт (носій) вже давно не відрефлексовує. Простий i брутальний приклад цього - відсутність громадян, які справляють нужду на вулиці, у публічних місцях і закладах при скупченні людей. Отже, така проста і суто біологічна потреба детермінована соціально і дитину змалечку привчають до норм поведінки в цій сфері. Так, установка об'єктивується в практиці. Неусвідомлюване отримує життя в дії, продовжуючи залишатись не об'єктивованим, але знайомим, призвичаєним. Важливо відзначити, що установка в контексті розуміння практики може бути окреслена лише як певний зміст, значення цієї практики. Як пише М. Полані, практичне знання завжди неявне. Людина часто не знає і не може пояснити, як саме вона щось робить, навіть якщо володіє цією навичкою досконало [13, с. 74]

Таким чином, «практики формуються, зберігаються i транслюються завдяки численним культурним та індивідуальним контекстам, що виступають в якості актуального особистісного, тілесного середовища», - пише Т. Титаренко [14]. Так, практика засвоюється, привласнюється індивідом, перетворюючись на природню частку життєвого патерну, маркер габітусу.

Практика виконує механічні прості задачі існування нашого тіла в соціуму і разом 3 цим вона $€$ тим, що нас культурно вбудовує в цей соціум, робить нас його елементом. Тілесність і рухливість робить практику вимірюваною, тобто доступною для обчислень і підрахунків у тих чи інших одиницях. Але важливим тут стає не те, скільки i яких саме рухів робить людина, відтворюючи ту чи іншу практику, а як, яким чином відбувається ця практика, які власне дії і в якій послідовності робить досліджуваний? Отже, дослідника цікавить конкретна форма репрезентації практики, алгоритм іiі перебігу, відтворення. Це важливо саме тому, що дає відповідь на головні питання науки про культуру і повсякденність, бо саме практика стає тим локусом перетину каузального з духовним, як культурним, видимого 3 невидимим, стає емпірично доступним мереживом кордонних значень, харизматичних змістів культури, які піддаються візуалізації.

3 неусвідомлюваності витікає i автоматизм практики. Оскільки гіпотетично неусвідомлюваність обов'язково передбачає автоматизм, то варто зазначити, що це є важлива ознака, яка нам дає розуміння того, що практика завжди є автоматичною. Так, автоматичність формується із повторюваності, бо кожну практику кожна людина повторює в своєму житті безліч разів. Може дещо трансформуватися виконання в силу стану здоров’я, як данині моді і т. д, але це не змінить функції практики (читай їі змісту), отже практика залишається все одно повторюваною. Саме повторюваність практики, як ми вже зазначали, протягом життя робить іï автоматичною і виміщає в передсвідоме, підсвідоме, в фон повсякденності [8].

Завершуючи, зазначимо, що загалом нами визначено, що в сучасній соціальній теорії під практиками розуміються узвичаєні рутинні соціальні дії, засновані на колективному досвіді суб'єктів, які мають певні атрибуції. На початку статті ми їх перераховували і тепер, підсумовуючи, варто зазначити, що саме вони визначають практику як таку і відрізняють ii від інших елементів культури.

Можна сказати, що перелік цих характеристик повною мірою описує специфіку практики як такої в сенсі соціальної дії, елемента культури, конструкта свідомості і маркера - індексу соціологічних досліджень. Визначені характеристики $є$ загальними для практик незалежно від того, $з$ якої позиції вони розглядаються і до якого типу належать. Саме вони визначають практику як практику, відрізняючи їі від інших елементів культурної системи.

Ознаки, атрибуції поняття практики мотивують і наш інтерес до структури практики як явища і тут цікавим буде те, що у випадку ціле раціональної діяльності першим у структурі дії буде думка, розмірковування, а потім дія, то у випадку практики дія буде викликана короткою командою-образом за принципом стимул-реакція, що не потребуватиме осмислення, розмірковування. Отже, в основі структури практики буде алгоритм дій як певна послідовність автоматичних рухів, передбачаючи іноді ту чи іншу маніпуляцію 3 предметами. В цьому сенсі рухи у складі практики можуть бути простими, складними, довільними і підпорядкованими, але вони обов'язково мають задану послідовність, як алгоритм, правило виконання. Практики теж можуть бути різними i, ймовірно, різні практики матимуть різний ступінь неусвідомлюваності, але це вже окрема тема. Важливо відзначити, що незалежно від ступеня осмислення, іiі виконання передбачає певний автоматизм. Так, автоматичність, або те що Е. Гідденс називає рутинність, а М. Вебер традиційною дією і $є$ родовою атрибуцією практики як такої.

\section{Висновки.}

Підсумовуючи наш кроткий аналіз зазначимо, що апріорні буденні дії, звичаєві поведінкові моделі, які складають тканину повсякденного життя людини - це те, що наразі чим далі, тим більше стає предметом уваги науковців, особливо соціологів. Неусвідомлюваність як характеристика практики стала причиною того, що практики часто називаються фоновими, латентними. Саме не- 
усвідомлюваність, автоматизм визначається нами як родова атрибуція цього поняття. Багаторазова повторюваність практики протягом життя робить ii автоматичною і виміщає пов'язану 3 нею при- родню установку в підсвідоме людини, а культурно - в той самий фон повсякденності, через який практика настільки сприймається як належне i звичайне, що не помічається, стає невидимою.

\section{БІБІЛІОГРАФІЧНІ ПОСИЛАННЯ}

1. Reckwitz A. Toward a Theory of Social Practices: A Development in Culturalist Theorizing / A. Reckwitz // European Journal of Social Theory. - 2002. - Vol. 5 (2). - P. 243-263.

2. Штомпка П. Социология социальных изменений / П. Штомка. - М.: Аспект-Пресс, 1996. -418 с.

3. Вахштайн В. С. Социология повседневности и теория фреймов / В. С. Вахштайн. - СПб.: Изд-во Европейского ун-та, 2011. $-287 \mathrm{c}$.

4. Schatzki T. Social practices: A Wittgensteinian approach to human activity and the social / T. Schatzki. - N.Y.: Cambridge University Press, 1996.

5. Бурдье П. Практический смысл / П. Бурдье; пер. с фр. А.Т. Бикбова, К.Д. Вознесенской, С.Н. Зенкина, Н.А. Шматко; общ. ред. и послесл. Н.А. Шматко. - СПб.: Алетейя, 2008. - 298 с.

6. Гидденс Э. Устроение общества: Очерк теории структурации / Э. Гидденс; пер. с англ. - М.: Академический проект, 2003. - $235 \mathrm{c}$.

7. Волков В. В. Теория практик / В. В. Волков, О. В. Хархордин. - СПб., 2008. - 298 с

8. Налимов В. В. Спонтанность сознания: Вероятностная теория смыслов и смысловая архитектоника личности /

В. В. Налимов. - М.: Изд-во «Прометей» МГПИ им. Ленина, 1989. - 325 с.

9. Клюев А. Интегральная психофизиология как инструмент адекватного отражения психической деятельности человека / А. Клюев, А. Качалкин // Прикладная психология. - 2000. - № 5. - С. 9-16.

10. Узнадзе Д. Н. Основные положения теории установки / Д. Н. Узнадзе // Экспериментальные основы психологии установки. - Тбилиси: 2001. - С. 12-68.

11. Шюц А. Смысловая структура повседневного мира: Очерки по феноменологической социологии / А. Шюц. М.: Ин-т Фонда «Общественное мнение», 2005. - 235 с.

12. Мельников А. Социологическая интерпретация экзистенциальных ценностей / А. Мельников // Соціологічні дослідження: зб. наук. праць. - Луганськ: СНУ ім. В. Даля, 2010. - № 10. - С. 130-142.

13. Полани М. Личностное знание / М. Полани; пер. с фр. - М.: Прогресс, 1985. - 287 с.

14.Титаренко Т. М. Психологічні практики конструювання життя в умовах постмодерної соціальності: монографія / Т. М. Титаренко, О. М. Кочубейник, К. О. Черемних; НАПН України, Ін-т соц. та політ. психології. - Київ: Міленіум, 2014. - 206 с.

\section{REFERENCES}

1.Reckwitz, A. (2002). Toward a Theory of Social Practices: A Development in Culturalist Theorizing. European Journal of Social Theory, 5 (2), 243-263.

2. Shtompka, P. (1996). Sotsyolohyia sotsyalnykh yzmenenyi [Sociology of social change]. Moscow: Aspekt-Press [in Russian].

3. Vakhshtain, V.S. (2011). Sotsyolohyia povsednevnosty y teoryia freimov [Sociology of everyday life and theory of frames]. SPb.: Yzd-vo Evropeiskoho un-ta [in Russian].

4. Schatzki, T. (1996). Social practices: A Wittgensteinian approach to human activity and the social. New York.: Cambridge University Press

5. Burde, P. (2008). Praktycheskyi smysl [Practical meaning]. SPb.: Aleteiia [in Russian].

6. Hyddens, E. (2003). Ustroenye obshchestva: Ocherk teoryy strukturatsyy [Society's outlook: An outline of the theory of structure]. Moscow: Akademycheskyi proekt [in Russian].

7. Volkov, V.V., \& Kharkhordyn, O.V. (2008). Teoryia praktyk [Theory of Practices]. SPb [in Russian].

8. Nalymov, V.V. (1989). Spontannost soznanyia: Veroiatnostnaia teoryia smyslov y smyslovaia arkhytektonyka lychnosty [Spontaneity of consciousness: Probabilistic theory of meanings and semantic architectonics of personality]. Moscow: Yzd-vo «Prometei» MHPY ym. Lenyna [in Russian].

9. Kliuev, A., \& Kachalkyn, A. (2000). Yntehralnaia psykhofyzyolohyia kak ynstrument adekvatnoho otrazhenyia psykhycheskoi deiatelnosty cheloveka [Integral psychophysiology as a tool for adequately reflecting a person's mental activity]. Prykladnaia psykholohyia, 5, 9-16 [in Russian].

10. Uznadze, D.N. (2001). Osnovnye polozhenyia teoryy ustanovky [Basic theories of the theory of installation]. Eksperymentalnye osnovy psykholohyy ustanovky. Tbylysy [in Russian].

11. Shiuts, A. (2005). Smyslovaia struktura povsednevnoho myra: Ocherky po fenomenolohycheskoi sotsyolohyy [Semantic Structure of the Everyday World: Essays on Phenomenological Sociology]. Moscow: Yn-t Fonda «Obshchestvennoe mnenye» [in Russian]. 
12. Melnykov, A. (2010). Sotsyolohycheskaia ynterpretatsyia ekzystentsyalnykh tsennostei [Sociological interpretation of existential values]. Sotsiolohichni doslidzhennia. Luhansk: SNU im. V. Dalia, 10, 130-142 [in Russian].

13. Polany, M. (1985). Lychnostnoe znanye [Personal knowledge]. Moscow: Prohress [in Russian].

14.Tytarenko, T.M., Kochubeinyk, O.M., \& Cheremnykh, K.O. (2014). Psykholohichni praktyky konstruiuvannia zhyttia $v$ umovakh postmodernoi sotsialnosti: monohrafia [Psychological practices of constructing life in the conditions of postmodern sociality]. Kyiv: Milenium [in Ukrainian].

\section{Настояща Катерина Василівна}

Кандидат соціологічних наук

Київський національний університет імені Тараса Шевченка

01601, Київ, вул. Володимирська, 64/13

\section{Nastoiashcha Kateryna}

$\mathrm{PhD}$ in Sociology

Taras Shevchenko National University of Kyiv

64/13, Volodymyrska Str., 01601, Kyiv, Ukraine

Email: kvitka2155@gmail.com

Цитування: Настояща К. В. Автоматизм соціальної практики як родова атрибуція поняття / К. В. Настояща // Науково-теоретичний альманах «Грані». - 2018. - Т. 21. - № 3. - С. 41-47

Citation: Nastoiashcha, K.V. (2018). Avtomatyzm sotsialnoi praktyky yak rodova atrybutsiia poniattia [Automatizm of social practice as a generic attribution of the concept]. Scientific and theoretical almanac «Grani», 21(3), 41-47. 